\title{
Transcriptional profile of maize roots under acid soil growth
}

Lucia Mattiello ${ }^{1}$, Matias Kirst ${ }^{2}$, Felipe R da Silva ${ }^{3}$, Renato A Jorge ${ }^{4}$, Marcelo Menossi ${ }^{i^{*}}$

\begin{abstract}
Background: Aluminum (Al) toxicity is one of the most important yield-limiting factors of many crops worldwide. The primary symptom of Al toxicity syndrome is the inhibition of root growth leading to poor water and nutrient absorption. Al tolerance has been extensively studied using hydroponic experiments. However, unlike soil conditions, this method does not address all of the components that are necessary for proper root growth and development. In the present study, we grew two maize genotypes with contrasting tolerance to Al in soil containing toxic levels of $\mathrm{Al}$ and then compared their transcriptomic responses.

Results: When grown in acid soil containing toxic levels of Al, the Al-sensitive genotype (S1587-17) showed greater root growth inhibition, more Al accumulation and more callose deposition in root tips than did the tolerant genotype (Cat100-6). Transcriptome profiling showed a higher number of genes differentially expressed in S1587-17 grown in acid soil, probably due to secondary effects of Al toxicity. Genes involved in the biosynthesis of organic acids, which are frequently associated with an Al tolerance response, were not differentially regulated in both genotypes after acid soil exposure. However, genes related to the biosynthesis of auxin, ethylene and lignin were up-regulated in the Al-sensitive genotype, indicating that these pathways might be associated with root growth inhibition. By comparing the two maize lines, we were able to discover genes up-regulated only in the Altolerant line that also presented higher absolute levels than those observed in the Al-sensitive line. These genes encoded a lipase hydrolase, a retinol dehydrogenase, a glycine-rich protein, a member of the WRKY transcriptional family and two unknown proteins.

Conclusions: This work provides the first characterization of the physiological and transcriptional responses of maize roots when grown in acid soil containing toxic levels of Al. The transcriptome profiles highlighted several pathways that are related to Al toxicity and tolerance during growth in acid soil. We found several genes that were not found in previous studies using hydroponic experiments, increasing our understanding of plant responses to acid soil. The use of two germplasms with markedly different Al tolerances allowed the identification of genes that are a valuable tool for assessing the mechanisms of Al tolerance in maize in acid soil.
\end{abstract}

\section{Background}

Acid soils are the most important cause of low yield for many crops [1]. About 30\% of the world's soils are acidic, and $60 \%$ of them are in tropical and subtropical areas associated with long periods of hot and moist weather [1]. Soil acidification is an increasing problem in the United States and Europe because of acid rain, removal of natural plant coverage from large production

\footnotetext{
* Correspondence: menossi@unicamp.br

'Laboratório de Genoma Funcional, Departamento de Genética, Evolução e Bioagentes, Instituto de Biologia, Universidade Estadual de Campinas,

Campinas, SP, Brazil

Full list of author information is available at the end of the article
}

areas and the use of ammonium-based fertilizers [2]. One of the major problems caused by soil acidification is aluminum $(\mathrm{Al})$ phytotoxicity. $\mathrm{Al}$ is the principal component of mineral soils and is present in a wide range of primary and secondary minerals [3]. In soils with $\mathrm{pH}$ above $5, \mathrm{Al}$ is precipitated predominately in gibsit form $\left(\mathrm{Al}(\mathrm{OH})_{3}\right)$ and has no phytotoxic effect. At lower $\mathrm{pH}, \mathrm{Al}$ $(\mathrm{OH})_{3}$ is solubilized and $\mathrm{Al}$ is released.

The most evident symptom of Al toxicity is the inhibition of root growth. In maize root tips, $\mathrm{Al}$ induces a rapid change in cell number and positioning [4], and recent evidence suggests that DNA damage and interference with cell-cycle progression and cell differentiation 
are the primary causes of root growth inhibition due to $\mathrm{Al}$ toxicity [5]. Other reported effects of $\mathrm{Al}$ exposure are the disruption of $\mathrm{Ca}^{2+}$ homeostasis [6,7], increased ACC oxidase activity with a consequent increase in ethylene production [8], Al binding to cell wall polysaccharides $[9,10]$ and reduced membrane fluidity [11].

To cope with $\mathrm{Al}$ stress, plants activate exclusion and tolerance mechanisms [1]. Exclusion mechanisms take place outside the roots and prevent the entry of $\mathrm{Al}$ into the cell. These mechanisms include cell wall $\mathrm{Al}$ immobilization, increased selective permeability of the plasma membrane, rhizosphere $\mathrm{pH}$ barrier formation and quelling by exudates such as organic acids and phenolic compounds [1,12-15]. Tolerance mechanisms are active after $\mathrm{Al}$ enters the cell - $\mathrm{Al}$ ions can be quelled in the cytosol, compartmentalized inside the vacuole or proteins that bind directly to Al may become highly expressed [12,16,17].

Among all of the proposed mechanisms, organic acid release is the most well-characterized resistance strategy used by plants. Since the first report demonstrating Alinduced malate secretion in wheat [18], several research groups have observed that organic acid exudation is higher in tolerant than sensitive genotypes in species such as snap beans [19], wheat [20] and maize [21-24]. However, in maize and wheat, organic acid release does not correlate with resistance in all genotypes, indicating that other mechanisms, such as active $\mathrm{Al}$ exclusion, may also play a relevant role [25-27]. Similarly, Maron et al. [28] and Kumari et al. [29] recently demonstrated that tolerance in maize and Arabidopsis is not associated with increased expression of genes encoding enzymes responsible for organic acid biosynthesis, but rather with differential expression of their transporters.

The identification of genes related to Al tolerance has indicated that a plethora of biological functions are influenced by this ion. With the advent of cDNA arrays, the evaluation of global gene expression changes in response to $\mathrm{Al}$ stress allowed the identification of a broader number of genes that are modulated by this ion [28-34]. Guo and colleagues [34] used isogenic lines of wheat with differential tolerance to $\mathrm{Al}$ and identified 28 differentially expressed genes, including malate transporters, a $\beta$-glucosidase, lectin and a histidine kinase. Kumari et al. [29] reported that exposure to $\mathrm{Al}$ induces several ribosomal protein genes, peptidases and phosphatases. Maron et al. [28] compared gene expression in two maize genotypes with contrasting $\mathrm{Al}$ tolerance and found that several genes involved in processes such as cell wall remodeling, response to oxidative stress and $\mathrm{Pi}$ starvation were differentially regulated.

While the identification of genes related to $\mathrm{Al}$ stress has led to a greater understanding of plant responses to this ion, these studies have been conducted mostly using hydroponic culture. This growth condition may not adequately mimic the soil environment with respect to rhizosphere development [35,36], which involves a complex mixture of microorganisms, border cells and mucilage [36]. Several other studies have addressed the role of mucilage in the detection and avoidance of $\mathrm{Al}$ toxicity. Horst et al. [37] demonstrated that $50 \%$ of all $\mathrm{Al}$ in root apexes of Vigna unguiculata is sequestered by the mucilage layer, and its removal increases root sensitivity to Al [37]. Similarly, Archambauldt et al. [38] found that mucilage production by sensitive varieties of wheat was inhibited more rapidly than that by tolerant varieties when exposed to phytotoxic levels of Al [38]. Similarly, Miyasaka and Hawes [36] found evidence that in snap beans, border cells are involved in detecting and avoiding $\mathrm{Al}$ toxicity. By contrast, $\mathrm{Li}$ et al. [39] observed that root growth inhibition in maize was not affected by the removal of root mucilage. These findings indicate that different species, or even different varieties of the same species, can present distinct resistance and/or tolerance mechanisms. Therefore, evaluating Al tolerance in conditions that are similar to those in the field may provide a better understanding of the mechanisms required to avoid Al toxicity.

Here we present an analysis of transcriptome changes in two maize varieties with contrasting levels of $\mathrm{Al}$ tolerance, using acid soil as the growth substrate. Our analysis identified genes in several metabolic pathways whose expression was modified when plants were growth in acid soil. While we found some Al-responsive genes previously identified in studies carried out in hydroponic growth conditions, growth in acid soil clearly also triggered a new suite of physiological and transcriptional responses not previously reported. Taken together, our results offer a more complete picture of the transcriptomic changes imposed by acid soils, and they may lead to the discovery of novel genes involved in Al tolerance.

\section{Results}

\section{Physiology of maize seedlings grown in acid soil}

Most recent studies aiming to characterize plant transcriptomic or proteomic responses to $\mathrm{Al}$ exposure have used hydroponic culture $[28,29,40]$. In the present study, soil was used as the substrate to better mimic field conditions and to allow the maintenance of all root apex components and root architecture. Plants were grown in Dark Red Latossol ( $\mathrm{pH} 4.1$ ) with an Al content of 10 $\mathrm{mmol}_{\mathrm{c}} / \mathrm{dm}^{3}$. As a control, the same soil was used, but with $\mathrm{pH}$ corrected to 5.5 (see Methods section). Two lines used in previous studies that evaluated $\mathrm{Al}$ tolerance in hydroponic growth conditions were characterized: Cat100-6 (Al-tolerant) and S1587-17 (Al-sensitive) [25,28,33,41-44]. S1587-17 is a somaclonal variant regenerated from a callus culture of Cat100-6 [42]. 


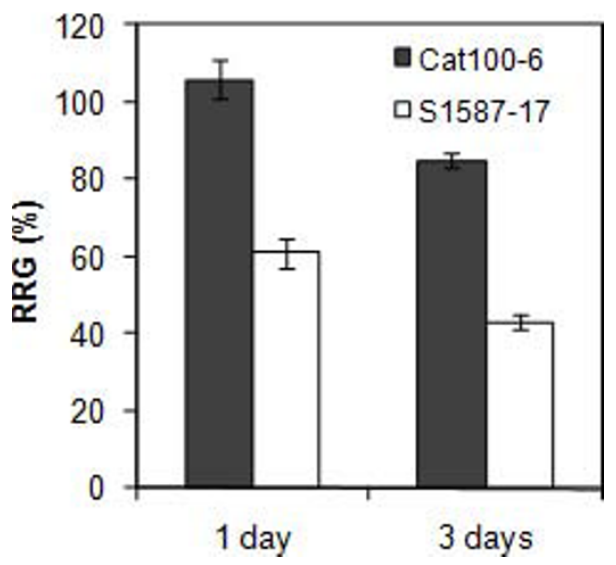

Figure 1 Effect of acid soil saturated with $\mathrm{Al}^{3+}$ on maize root growth. Plants were grown in acid ( $\mathrm{pH} 4$ 4.2) or control ( $\mathrm{pH}$ 5.5) soil for one or three days. The growth is relative to the control soil $(\mathrm{pH}$ 5.5). Vertical error bars represent mean \pm SE $(n=20)$. The difference between the two lines in each treatment was significant at $p<0.05$.

Relative root growth (RRG) was measured after one and three days of growth in soil. The Al-sensitive plants were severely affected by acid soil at both time points, while the Al-tolerant plants were affected only after three days and to a significantly lower extent (Figure 1; see also Additional file 1: Figure S1). Both maize genotypes had higher levels of callose when grown in acid soil, a response typically correlated with Al stress [45-47]. However, the increase in callose content was significantly higher in the Al-sensitive line (Figure 2). To investigate whether the root inhibition and callose accumulation were due to $\mathrm{Al}$ phytotoxicity associated with acid soil, the $\mathrm{Al}$ absorbed by root tips was quantified after one and three days of soil exposure. Figure 3

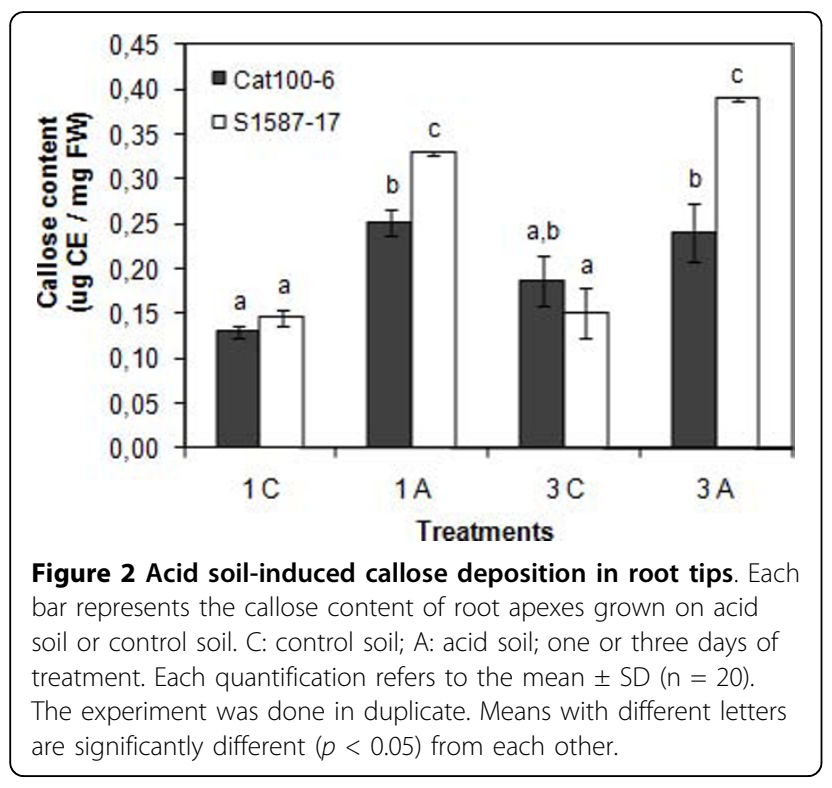

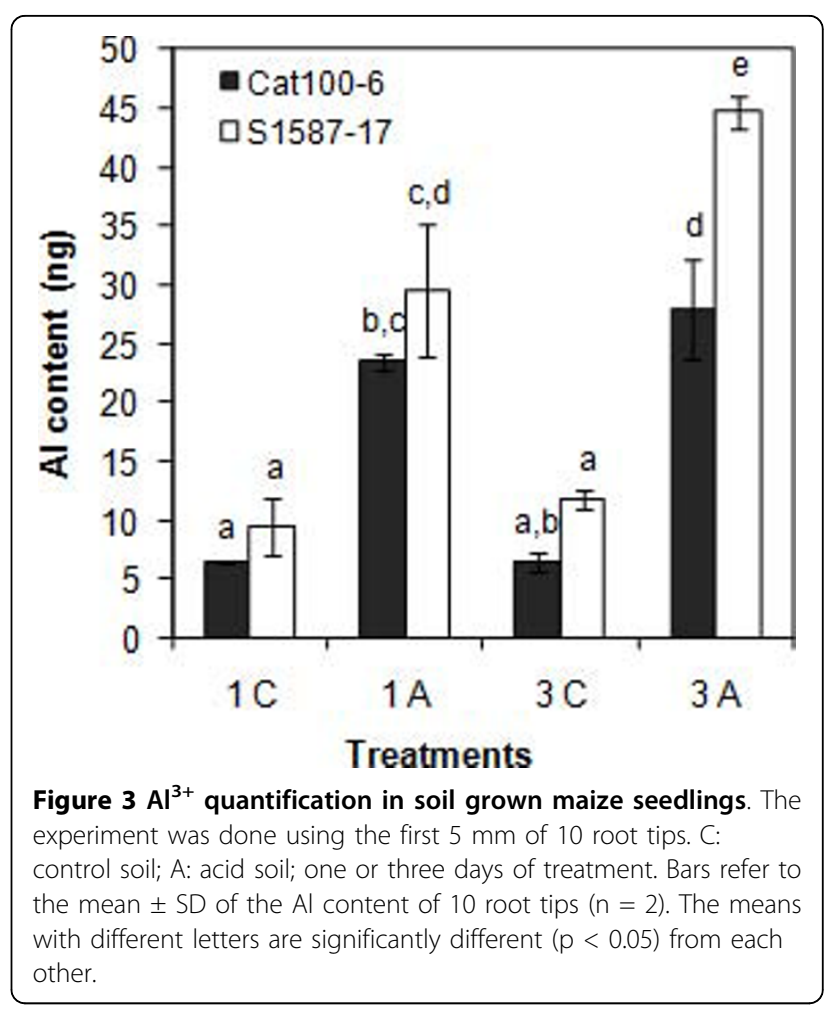

demonstrates that the sensitive line S1587-17 had significantly higher amounts of Al than the Al-tolerant variety. These results indicate that these maize varieties have different physiological responses to acid soil and that these responses are most likely due to the presence of Al. Nevertheless, we cannot exclude the possibility that $\mathrm{pH}$ also contributes to plant responses during acid soil exposure.

\section{Gene Expression Profiling}

The Affymetrix GeneChip ${ }^{\oplus}$ Maize Genome Array was used to evaluate the transcriptional response of the two contrasting maize genotypes to growth in acid soil. Analysis of variance (ANOVA) was used to dissect the transcriptional responses associated with the individual maize lines (independent of soil treatment or time of exposure), time of collection ( 1 and 3 days), soil type (control or acid soil treated) and all possible interactions (see Methods section). In the Al-tolerant line (Cat100-6) exposed to acid soil for one day, only eight genes were differentially expressed compared to plants grown in control soil (Figure $4 \mathrm{~A}$ ). The number of differentially regulated genes increased (59) after three days of treatment (Figure 4B). However, the Al-sensitive maize line showed a significantly higher number of differentially expressed genes. On the first day, 339 genes were differentially regulated (Figure $4 C$ ), while 776 were affected by the treatment on the third day (Figure 4D). The genes that were differentially 


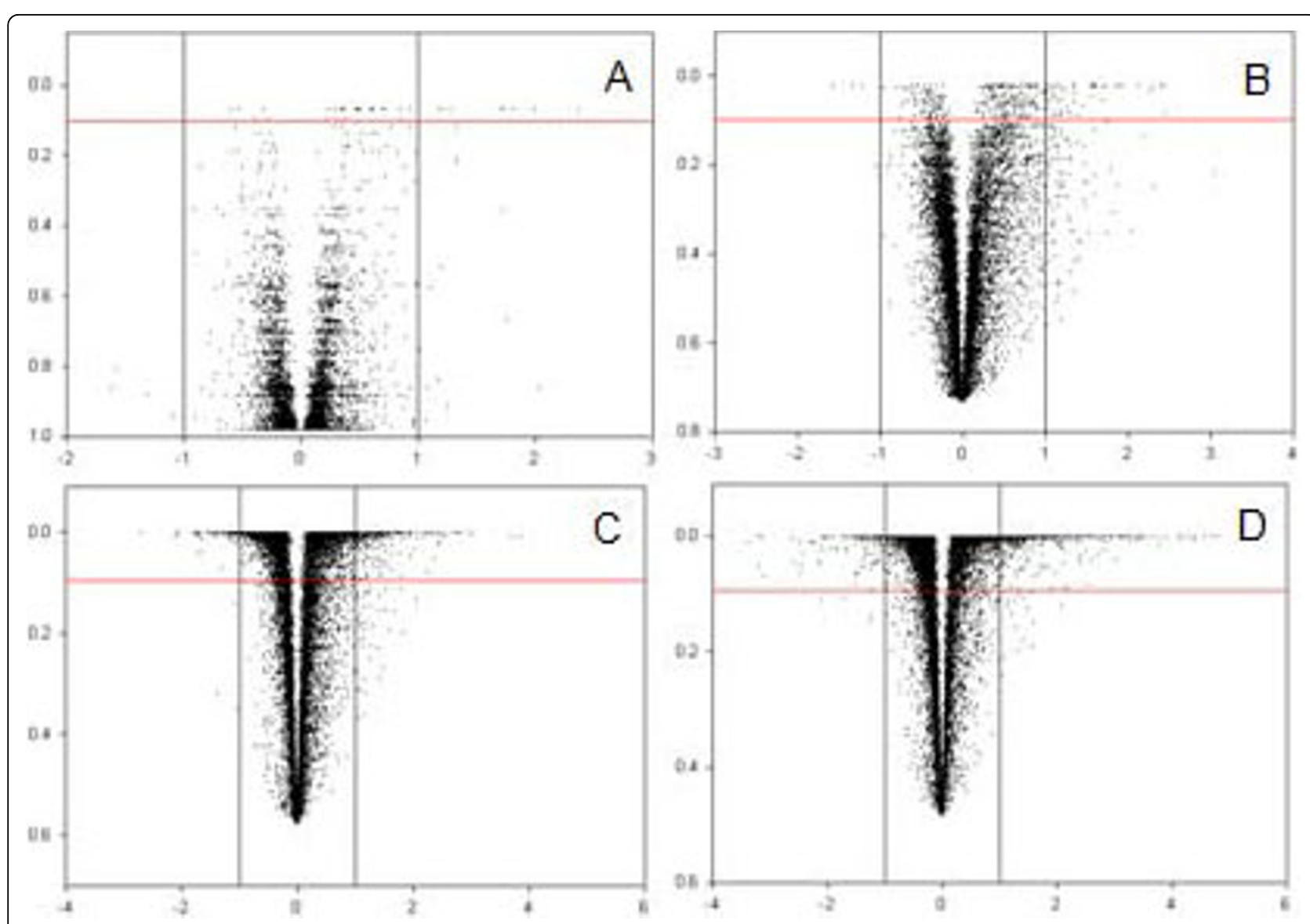

Figure 4 Volcano plots representing interactions of various effects. Estimates were calculated as the difference between the least-square means for each comparison ( $\mathrm{x}$-axis). Estimates equal to zero represent no expression change and estimates different from zero represent gene expression modifications. A: interaction effect between genotype, treatment and time for Cat100-6 one day; B: interaction effect between genotype, treatment and time Cat100-6 three days; C: interaction effect between genotype, treatment and time S1587-17 one day; D: interaction effect between genotype, treatment and time S1587-17 three days. The red line represents an FDR of 10\%, and consequently data points above this line represent significant observations (the $y$-axis represents Qvalues). Note that the Estimate axis is different for each plot.

regulated under all conditions are described in the Additional file 2 (Tables S1-S4), and the number of genes upor down-regulated in each genotype and at each time point is shown in Figure 5.
Figure 6 depicts the number of genes differentially regulated between acid and control soil conditions that are unique or shared between S1587-17 and Cat100-6 at each time point. All of the eight genes differentially regulated

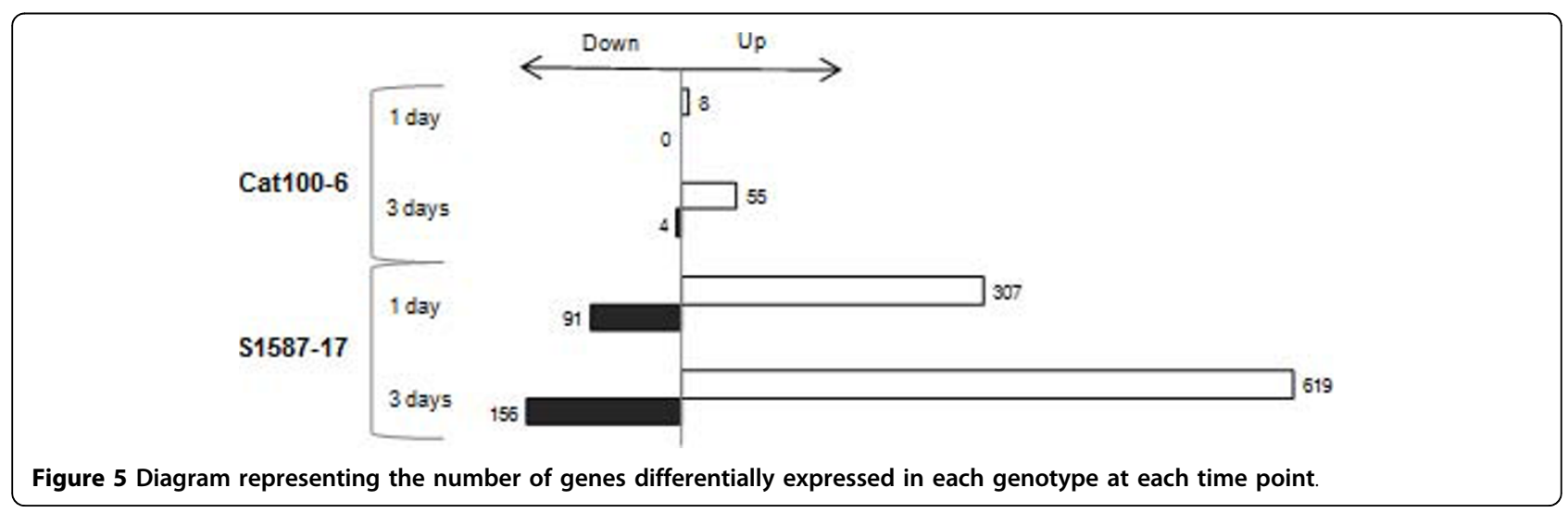




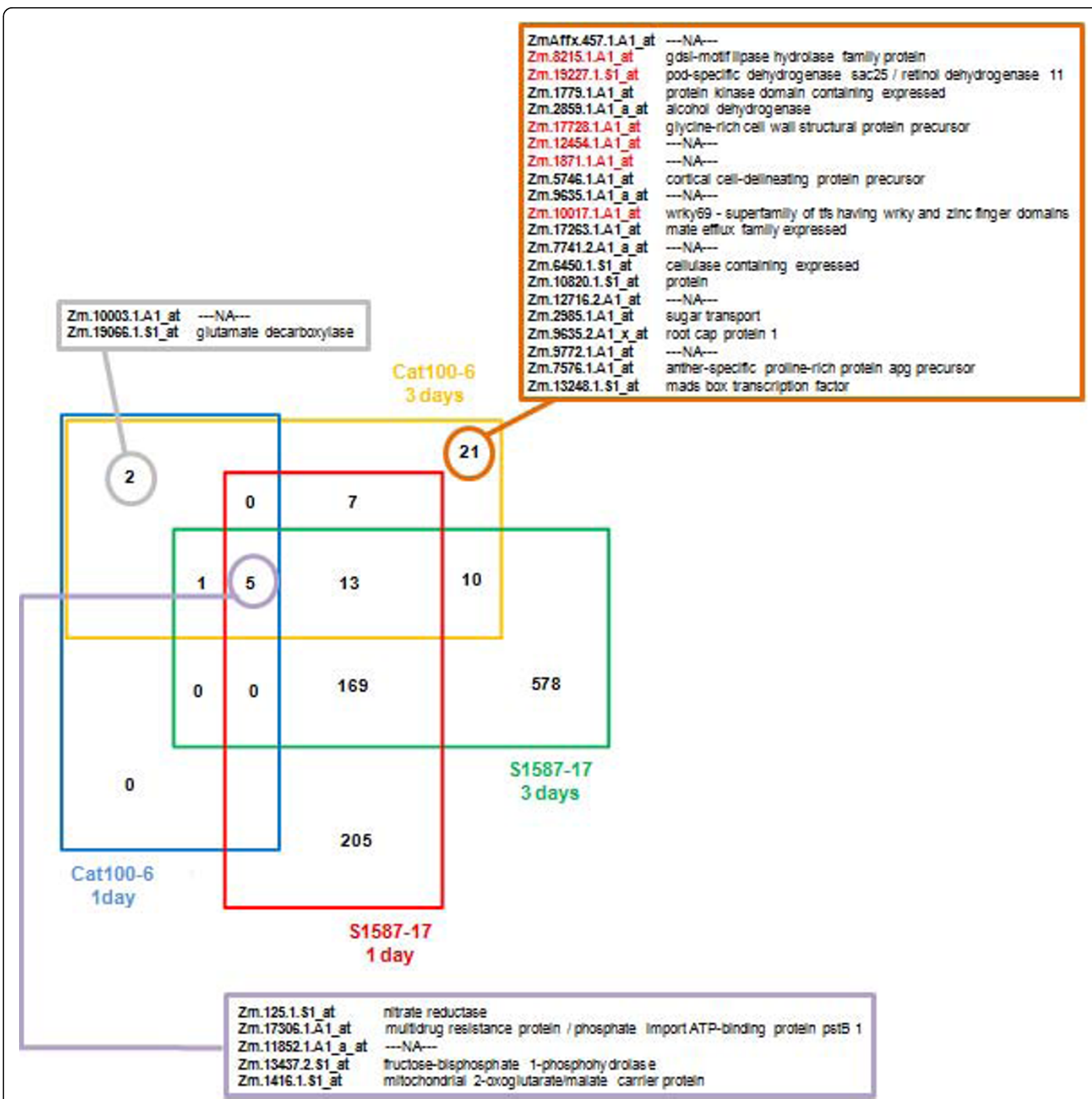

Figure 6 Multiple comparison Venn diagram. Each quarter represents a list of IDs of genes differentially expressed in the comparison between acid and control soils for each maize variety. The boxes indicate the Affymetrix ID and the annotation of the genes identified only in Cat100-6 (both time points - grey box), in all genotypes and time points (purple box) and genes identified only in Cat100-6 after three days (orange box - the genes identified in red are those that also presented significantly higher expression values in Cat100-6 in the comparison between genotypes after three days in acid soil).

on day 1 in Cat100-6 were up-regulated, and they were also detected after three days of acid soil exposure. Only two genes were exclusively detected in the Al-tolerant line: Zm.10003.1.A1_at (no hit) and Zm.19066.1.S1_at (glutamate decarboxylase). Five genes were differentially expressed in both S1587-17 and Cat100-6 at one and three days: Zm.125.1.S1_at (nitrate reductase),
Zm.17306.1.A1_at (multidrug resistance protein/phosphate import ATP-binding protein pstB 1), Zm.11852.1. A1_a_at (no hit), Zm.13437.2.S1_at (fructose-bisphosphate 1-phosphohydrolase) and Zm1416.1.S1_at (mitochondrial 2-oxoglutarate/malate carrier protein).

To further evaluate the quantitative extent by which genes were differentially regulated between the two 
maize lines, the difference in the least-square means estimates (DEs) of gene expression levels between Cat100-6 and S1587-17 grown in acid soil were calculated at each time point (e.g., Cat100-6 in acid soil for three days versus S1587-17 in acid soil for three days), and the statistical significance was assessed. We aimed to identify genes induced by acid soil in Cat100-6 that also had significantly higher absolute levels than in S1587-17. We observed that none of the genes differentially expressed in Cat100-6 after one day of acid soil treatment presented significantly higher expression levels than in S1587-17 under the same conditions. However, eight genes out of the 59 differentially expressed in Cat100-6 after three days were also significantly more highly expressed relative to S1587-17 growing in acid soil for three days. Six of these genes are in the group of 21 exclusively identified as differentially regulated in Cat100-6 after three days (Figure 6), while the other two were also differentially expressed in S1587-17 after three days (Zm.3371.1.A1_at - O-methyltransferase and $\mathrm{Zm} .8742 .1$.A1_at - unknown protein).

Due to the large number of genes identified in the $\mathrm{Al}$ sensitive maize, a functional analysis was performed with Gene Ontologies to help identify the pathways affected by the toxicity imposed by acid soil. Most of the genes up-regulated on the first day are involved in lipid metabolism, oxidative stress responses and cell wall metabolism (Additional file 1: Figure S2A). Most of the genes down-regulated on the first day encode proteins involved in DNA packaging and cell cycle (Additional file 1: Figure S2B). Most of the genes up-regulated on the third day are involved in cell wall metabolism, oxidative stress responses and anionic transport (Additional file 1: Figure S3A). On the other hand, most of the repressed genes are involved in protein metabolism (Additional file 1: Figure S3B).

\section{Validation of gene expression profiles using qPCR}

To validate the microarray results, eleven differentially expressed genes were selected and real-time qPCR was performed (Figure 7). This validation was done with two independent biological replicates (different from the replicates used for the microarray experiment). A significant correlation between the two data sets was observed $\left(R^{2}=0.8812\right)$.

\section{Comparison with gene expression responses to $\mathrm{Al}$ treatment in hydroponic culture}

The soil treatment used in this work has two major variables that must be considered, the presence of phytotoxic $\mathrm{Al}$ and the $\mathrm{pH}$. However, it is not possible to separate these properties in the soil or even use a different acid soil with no Al because diversity in the physical and chemical characteristics would affect the results.

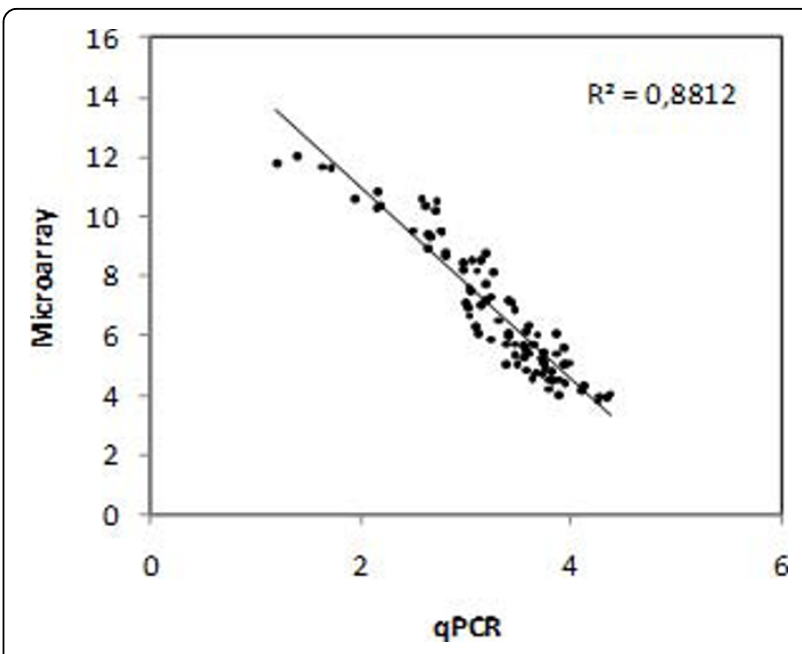

Figure 7 Real-time qPCR validation of the microarray results. The $\mathrm{qPCR}$ data were $\log _{2}$ transformed and plotted against the microarray data (least-square means). The correlation is negative because in the GPCR data, the more the gene is expressed the lower is its Ct value.

Therefore, hydroponic culture has been used to evaluate the effects of $\mathrm{pH}$ and $\mathrm{Al}$ levels on the expression of selected genes. Six out of the eight acid soil-induced genes from Cat100-6 that also had absolute levels higher than those of S1587-17 were used in an experiment consisting of three treatments: $\mathrm{pH} 5.5 ; \mathrm{pH} 4.2$ with no $\mathrm{Al}$ and $\mathrm{pH} 4.2$ with $36 \mu \mathrm{M} \mathrm{Al}$. The effect on gene expression in Cat100-6 seedlings is illustrated in Figure $8 \mathrm{~A}$ (pH-effect, using pH 5.5 as the reference). The relative expression in seedlings grown in $\mathrm{pH} 4.2$ with $\mathrm{Al}$ relative to $\mathrm{pH} 4.2$ without $\mathrm{Al}$ (Al-effect) is shown in Figure 8B. Genes such as Zm.8215.1.A1_at (GDSL-motif lipase hydrolase family protein), Zm.17728.1.A1_at (glycine-rich cell wall structural protein precursor) and Zm.12454.1.A1_at (protein with unknown function) showed no significant differential regulation under treatment with $\mathrm{pH} 4.2$ in the presence or absence of $\mathrm{Al}$ or between $\mathrm{pH} 4.2$ and $\mathrm{pH} 5.5$ treatments, suggesting significant differences between the gene expression profiles from the hydroponic and soil experiments. However, Zm.19227.1.S1_at (Pod-specific dehydrogenase SAC25/ retinol dehydrogenase 11), Zm.1871.1.A1_at (protein with unknown function) and Zm.10017.1.A1_at (WRKY 69 transcription factor) were up-regulated in the presence of $\mathrm{Al}$, indicating that $\mathrm{Al}$ and not $\mathrm{pH}$ was the main factor behind their induction in the soil treatment.

To further highlight the different responses of maize when grown in hydroponics versus soil, we compared the target sequences from the Affymetrix platform used in this work with the target sequences from Maron et al. [28]. We observed that only a fraction of the genes modulated by $\mathrm{Al}$ in Cat100-6 grown in the hydroponic 


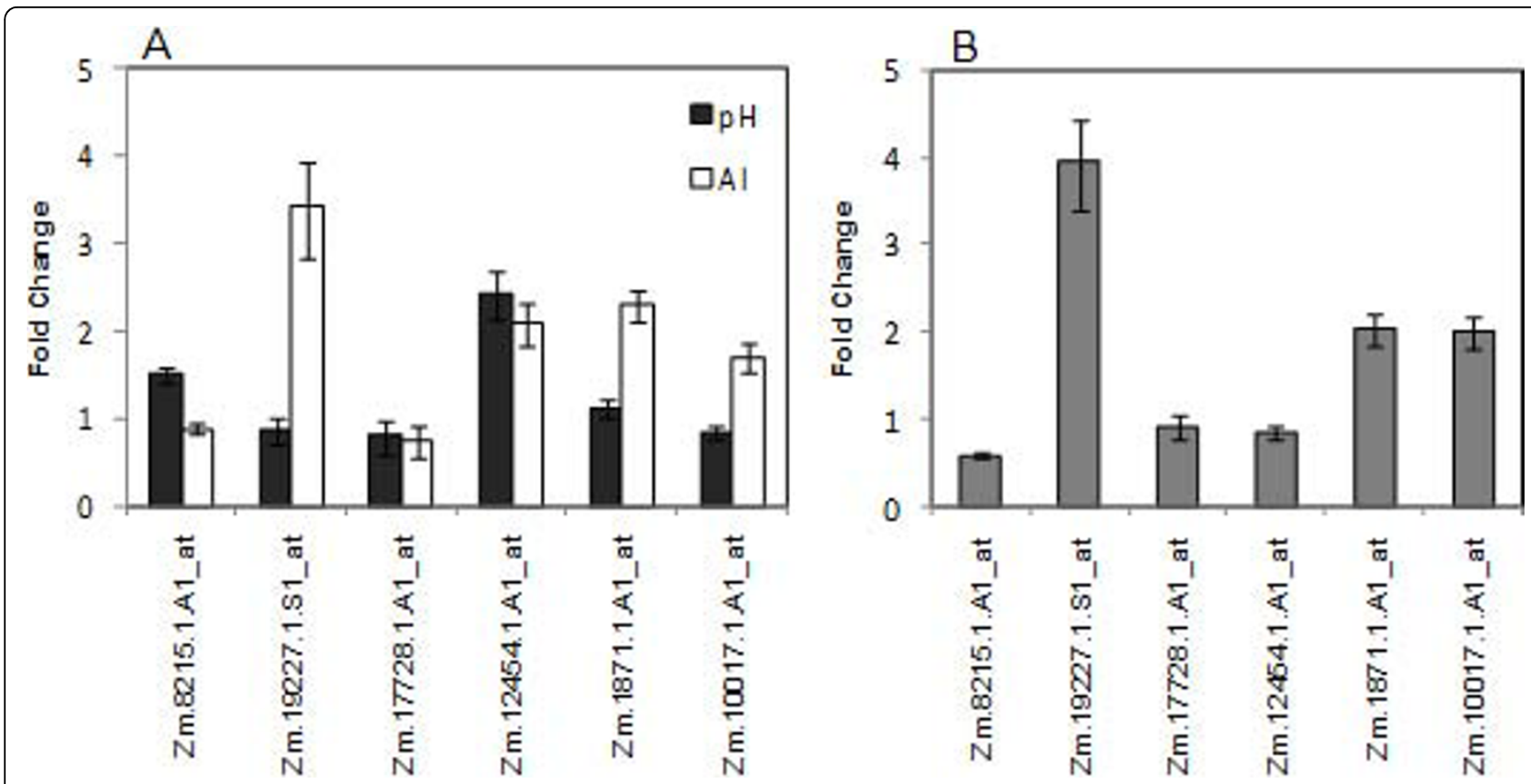

Figure 8 Expression of selected genes after hydroponic culture. (A) Data show the relative expression (in fold change) in relation to pH 5.5; (B) Data show the relative expression (in fold change) of the treatment with $\mathrm{pH} 4.2$ plus Al versus pH 4.2 without Al. The results are from three independent biological replicates.

experiment were also modulated in acid soil-grown plants: of the 59 genes differentially expressed in Cat100-6 grown in soil, only six were also found in the hydroponic assay. We also compared our data from S1587-17 with the data from the Al-sensitive line L53 because in the work of Maron et al., [28] S1587-17 was not used. In this case, the differences were even higher because only 34 out 952 genes modulated in S1587-17 were common to both gene sets. A complete list of the genes found in both experiments is shown in Additional file 2: Table S5.

\section{Discussion}

\section{Physiology of maize roots grown in acid soil}

Plant tolerance to $\mathrm{Al}$ is usually evaluated using hydroponic culture [48-53], but conflicting results may be obtained when compared to soil conditions [54,55]. Even when $\mathrm{Al}$ tolerance is consistent between hydroponic and soil conditions [56-60], plant responses may differ in the two growth systems. To address this limitation, we evaluated maize tolerance to acid soil containing $10 \mathrm{mmol}_{\mathrm{c}} / \mathrm{dm}^{3}$ (equivalent to $90 \mathrm{ppm}$ ) of $\mathrm{Al}$ and at $\mathrm{pH}$ 4.2. These conditions are within the range of previous studies and are sufficient to elicit a phytotoxic response [35,61-63], allowing phenotypic discrimination between two maize lines with distinct levels of resistance to Al, Cat100-6 (tolerant) and S1587-17 (sensitive). As shown in previous studies using these and other maize lines [25,28,39-42,46], Cat100-6 accumulated less $\mathrm{Al}$ in its root tips when grown in acid soil when compared to S1587-17. The amount of $\mathrm{Al}$ absorbed by root tips is indicative of the sensitivity of plants to this abiotic stress $[13,64,65]$, presumably because genotypes that accumulate less $\mathrm{Al}$ in their root apexes have a more efficient exclusion mechanism. However, after prolonged exposure ( 3 - 5 days), the amount of $\mathrm{Al}$ in Cat100-6 roots continued to increase (although at a lower rate than in S1587-17), in disagreement with previous studies that reported a reduction in $\mathrm{Al}$ accumulation in root tips after 24 hours in hydroponics $[28,41]$. Therefore, the exclusion mechanism of Cat100-6 appears to have less activity in soil than in hydroponic conditions. Nonetheless, Al-induced root growth inhibition and callose formation were markedly more limited in Cat100-6 than in S1587-17.

\section{Gene expression profiles of an Al-tolerant and an Al- sensitive maize line}

The abiotic stress caused by the toxicity of acid soil was clearly reflected in the gene expression profiles. The number of genes differentially regulated between control and treated (acid soil) plants increased in both Cat100-6 and S1587-17 when they were exposed to the stress for an extended period. It is worth mentioning that these changes observed in the transcriptome certainly reflect both direct and indirect effects of the stress caused by acid soil. In the field, where roots continuously grow and explore different soil regions, this is also certainly 
true. Interestingly, a smaller fraction of the transcriptome responded to acid soil stress in the resistant line Cat100-6 than in S1587-17, similarly to previous reports using $\mathrm{Al}$ and hydroponics $[28,33,66]$. Therefore, part of the resistance of Cat100-6 (and Al-tolerant plants generally) may involve a mechanism that limits major disturbances to plant function and thereby avoids a cascade of detrimental downstream effects.

Genes that are modulated by a stress are natural candidates for explaining the defenses activated by plants. By using contrasting genotypes it is possible to narrow the scope to genes with a higher probability of playing major roles in the plant response. Therefore, we selected eight genes that were more highly expressed in Cat100-6 than in S1587-17 under acid soil conditions. Six of these genes were also found to be induced by acid soil only in Cat100-6, while two were also induced in S1587-17, although to a lesser degree. We further characterized those six genes that were specific to Cat100-6, which encoded a GDSL-motif lipase hydrolase family protein, a pod-specific dehydrogenase/retinol dehydrogenase 11, a glycine-rich protein (GRP), a member of the WRKY transcriptional factor family and two unknown proteins. However, the hydroponic experiment demonstrated that only three of these genes have interesting expression patterns (up-regulated during $\mathrm{Al}$ treatment - Figure 8). Although further work will be needed to assess the individual contribution of each gene to acid soil tolerance, these data give insight into the strategies used by plants in fields where this stress takes place.

Zm.19227.1.S1_at (Pod-specific dehydrogenase/retinol dehydrogenase 11) was first described as a gene involved in rape oilseed pod development [67]. Members of this family may function as a bridging molecule between the nutritional signaling pathway and the hormone biosynthesis pathway in Arabidopsis [68]. This member is associated with ABA production and is critical for growth and development, and also for plant responses to stress via glucose signaling [68].

The WRKY family of transcription factors was first identified in plants and presents a high number of members [69]. About 70 members have been indentified in Arabidopsis, and several of them are induced in response to wounding, pathogen infection and abiotic stresses such as drought, cold and salinity [31,69-71]. Our microarray experiment indentified Zm.10017.1.A1_at (WRKY69) as differentially expressed in Cat100-6 after three days of acid soil treatment and also as presenting higher expression than in the Al-sensitive S1587-17 genotype. Hydroponic gene expression experiments also demonstrated that $\mathrm{Al}$ induces the expression of this gene. Kumari and colleagues [29] identified two WRKY family members as being downregulated after exposure of Arabidopsis to Al. Meanwhile, Goodwin and Sutter [72], also studying Arabidopsis, identified WRKY 33 as up-regulated due to Al treatment. An additional study identified another WRKY member as up-regulated due to $\mathrm{Al}$ and $\mathrm{Cd}$ stress. Using the same tolerant variety (Cat100-6) Maron et al. [28] identified two WRKY family members after $6 \mathrm{~h}$ of $\mathrm{Al}$ treatment. These results suggest that this transcription factor may be involved in the regulation of other genes that contribute to acid soil tolerance in plants.

Zm.1871.1.A1_at is a protein with unknown function that was up-regulated in acid soil and in hydroponics, indicating that $\mathrm{Al}$ rather than low $\mathrm{pH}$ is the inducer. Interestingly, this protein has a conserved domain typical of methyltransferases (MTase), which are responsible for methylation of several cellular components such as DNA, RNA, proteins and also small molecules [73]. These enzymes may also play important roles in disease resistance, growth and development [74]. Studies with rice [75], Arabidopsis [76] and tomato [40] have also identified members of this family as up-regulated after $\mathrm{Al}$ treatment. This is the first study to detect a potential role in acid soil tolerance for this maize protein.

A comparison of the transcriptional profile of roots grown in soil (this work) with that of roots grown hydroponically [28] showed only a minor overlap between these two growth systems. Although such comparisons are difficult because of differences in the chip platforms, conditions in different laboratories and other aspects, it strongly suggest that root responses in acid soil differ at least in part from those observed in hydroponic experiments. However, several pathways that are affected by $\mathrm{Al}$ in hydroponics were also observed in acid soil grown plants, as discussed below.

\section{Organic acid biosynthesis}

Of particular interest are genes involved in organic acid biosynthesis, which can protect the plant from deleterious effects of Al by binding to it after being secreted by root apexes [77]. However, only one gene belonging to an organic acid biosynthesis pathway was identified as downregulated in S1587-17 after a three-day treatment (citrate synthase - Zm.15069.1.A1_at). Previous studies have suggested that Cat100-6 activates pre-existing anionic channels after exposure to $\mathrm{Al}$ but prior to activation of the organic acid biosynthesis pathways [23,25]. It has also been observed that the levels of citrate exudation induced by $\mathrm{Al}$ in Cat100-6 roots is higher than in other $\mathrm{Al}$-sensitive genotypes (such as L53), but it stays constant over time [28], although no correlation between organic acid exudation and $\mathrm{Al}$-alteration of genes of the organic acid biosynthetic pathway has been observed in maize $[28,33]$.

\section{Oxidative stress in soil grown plants}

Plant cells normally produce reactive oxygen species (ROS) due to cellular processes that result in reduction 
of oxygen molecules. Plants have several enzymes capable of producing ROS and others that fight ROS to avoid cellular damage. Al toxicity can lead to an imbalance that results in oxidative stress and increases in the activity of enzymes and genes that reduce ROS effects, as previously observed in maize $[28,33,41,78,79]$ and other plant species [80-84]. Specifically in the case of the two maize lines used in this work, a previous study indicates that S1587-17 produces higher levels of ROS under $\mathrm{Al}$ stress, while $\mathrm{ROS}$ production remains constant in Cat100-6 [41]. Expectedly, genes involved in ROS production such as an oxalate oxidase (Zm.503.1.A1_at) and four germins (Zm.1315.1.A1_at; Zm.2525.1.A1_at; Zm.842.1.A1_at and Zm.9049.1.A1_x_at) were up-regulated in S1587-17 after acid soil treatment. In contrast, the up-regulation of genes implicated in the production of ROS was not detected in the Al-tolerant genotype Cat100-6 under stress.

Higher expression of oxalate oxidases in S1587-17 was also correlated with the up-regulation of peroxidases in the $\mathrm{Al}$-sensitive genotype. A gene encoding a glutathione peroxidase (Zm.6103.1.A1_a_at) was up-regulated in the Al-sensitive line, confirming the data obtained by Boscolo et al. [41], who found higher levels of this enzyme in S1787-17 under Al stress. In fact, more ROS scavenging genes were differentially expressed in S1587-17 than in Cat100-6, possibly reflecting a response to the up-regulation of ROS-producing genes. These data are in agreement with those from Maron et al. [28] suggesting that Cat100-6 has mechanisms that act before the oxidative stress takes place. However, none of the genes encoding superoxide dismutase were identified as up-regulated in S1787-17, in contrast to the induction of this enzyme [41] and transcriptional up-regulation detected previously in hydroponics [28].

The degree of ROS production and the enzymes involved in their metabolism may partially explain the differences in root growth detected in S1587-17 and Cat100-6 in acid soil. Together with oxalate oxidase, peroxidases act to remodel the cell wall during development and stress responses $[85,86]$. Our results indicate that the elevated number of peroxidases up-regulated in S1587-17 may be one of the causes of the root inhibition in this genotype, either by increasing ROS production or by changing the cell wall structure. On the other hand, Cat100-6 appears to be more effective at preventing ROS generation. This is supported by the smaller number of genes contributing to ROS production compared to the number observed in hydroponic culture $[28,33]$ and also by the constitutive (i.e., independent of soil type) expression of ROS scavenging genes (such as GST) in Cat100-6.

\section{The phenylpropanoid pathway is activated in Al-sensitive} maize plants

The higher expression of peroxidases in S171587-17 in acid soil was also correlated with an increase in the expression of several genes implicated in the synthesis of monolignols. Genes related to lignin biosynthesis have often been identified as responding to $\mathrm{Al}$ stress in monocots $[28,33,87,88]$, and higher lignin deposition has been associated with root growth inhibition in Al-sensitive wheat genotypes [87]. The phenylpropanoid pathway is the last biochemical step in the production of monolignols and the lignin polymer. The up-regulation of genes in the shikimate pathway, including shikimate kinases (Zm.3954.1.A1_at and Zm.10310.1.A1_at, are up-regulated in S1587-17/3 days) and chorismate mutase (up-regulated in S1587-17, Zm.9783.1.A1_at and Zm.10652.1.S1_at, and Zm.9867.1.A1_at constitutively expressed in Cat100-6) might increase the production of phenylalanine, the precursor for the phenylpropanoid pathway. Cinnamoyl-reductase (Zm.3297.1.A1_at) and several O-methyltransferases were up-regulated at days 1 and 3 in the Al-sensitive line, indicating that S1587-17 might accumulate lignin, reducing root growth. Similarly, several genes related to callose biosynthesis were up-regulated in the $\mathrm{Al}$-sensitive line at both time points (Zm.16347.1.A1_at - beta-glucan binding protein; Zm.14573.1.S1_at - glucan endo-beta-glucosidase 7 precursor; Zm.5768.1.A1_at - beta-glucanase precursor and Zm.12098.1.A1_at - endo-1,3;1,4-beta-d-glucanase precursor), corroborating the physiological data that show higher levels of callose in S1587-17.

\section{Insights into hormonal responses to acid soil}

Al has also been shown to impact root growth by modifying the levels of phytohormones such as auxin [89] and ethylene [8]. Genes encoding enzymes involved in auxin biosynthesis such as IAA amidohydrolase (Zm.3056.1.A1_at) and anthranilate phosphoribosyltransferase (Zm.1556.1.A1_at) were up-regulated in the root apex of the sensitive line S1587-17 when under acid soil stress, while the auxin-degrading enzyme indole-3-acetate beta-glucosyltransferase (Zm.18805.1. A1_at) was down-regulated after three days of acid soil exposure. Although auxin can induce new root formation, higher concentrations inhibit root elongation and enhance adventitious root formation. The genotype S1587-17 grown in acid soil developed significantly more lateral roots compared to plants grown under control conditions (data not shown). In coordination with the up-regulation of auxin-responsive genes (Zm.16990.1.S1_at, Zm.255.1.A1_at and Zm.5214.1. S1_at), its F-box receptor [90] was also up-regulated in S1587-17 (Zm.15393.1.S1_at). This might indicate a 
compensatory mechanism of primary root inhibition and lateral root stimulation to avoid nutrient and water deficiencies.

The transcriptome response of the $\mathrm{Al}$-susceptible line S1587-17 to acid soil treatment also involved the upregulation of two ACC oxidases (Zm.18900.1.S1_at and Zm.7909.1.A1_at), suggesting activation of the ethylene production pathway. The phytohormone ethylene mediates root growth inhibition [91,92], and treatment with inhibitors of ethylene perception increases root elongation [93]. Therefore, increased ethylene production is involved in root growth inhibition in the Al-sensitive genotype, and this response might be modulated not only by the germplasm but also by the culture conditions.

\section{Conclusion}

In this study we have characterized the transcriptomic changes of maize roots growing in acid soil containing toxic levels of Al. Our data highlighted several metabolic pathways that are challenged due to the stress caused by acid soil, including those involved with ROS production and detoxification, cell wall structure and hormone biosynthesis. Several genes previously reported as up-regulated by $\mathrm{Al}$ treatment in hydroponic experiments were also identified in acid soil grown plants. Most interestingly, we found genes that provide interesting clues to the mechanisms underlying the acid soil tolerance of an Al-tolerant maize line. These genes encode a GDSLmotif lipase hydrolase family protein, a pod-specific dehydrogenase/retinol dehydrogenase 11, GRP, WRKY and two proteins of unknown function. Taken together, these data provide a better understanding of the basis of Al toxicity and tolerance in acid soils.

\section{Methods}

\section{Plant material and growth conditions}

Seeds from the tropical maize (Zea mays L.) inbred lines Cat100-6 and S1587-17 were geminated for two days in moist filter paper. Seedlings with similar initial root length were transferred to 0.5 -liter plastic pots with $1 \mathrm{~kg}$ of soil (with $15 \%$ water $-\mathrm{mL} / \mathrm{Kg}$ ). Each bag received 20 seedlings, which were grown in a growth chamber at $26^{\circ}$ C (light: dark, 16:8 h). Bags were weighed twice daily and the weight was completed with distilled water to maintain the humidity at $15 \%$.

Plants were grown in a Dark Red Latossol sieved through a 4-mm mesh. Soil analysis indicted a $\mathrm{pH}$ of 4.1 and $\mathrm{Al}$ content of $10 \mathrm{mmol}_{\mathrm{c}} / \mathrm{dm}^{3}$ (referred to as the acid soil treatment). Fertilization was applied to avoid nutritional stress and consisted of the following nutrients (mg/Kg of soil): 56 of N; 38.75 of P; 78 of K; 32 of S; 60 of Mg; 0.5 of B; 0.5 of $\mathrm{Cu}$; 0.01 of Mo; 1.0 of $\mathrm{Zn}$. The soil used in the control treatment was incubated with
$0.8 \mathrm{~g}$ of $\mathrm{Ca}(\mathrm{OH})_{2}$ per $\mathrm{Kg}$ for one week prior the fertilization and the same amount of nutrient was added to the acid soil. The incubation with $\mathrm{Ca}(\mathrm{OH})_{2}$ increased the $\mathrm{pH}$ to $\mathrm{pH} 5.5$ and the presence of free $\mathrm{Al}$ was no longer detected. The acid soil also received a correction for $\mathrm{Ca}$ through the addition of a $\mathrm{CaCl}_{2}$ solution to compensate for the $\mathrm{Ca}(\mathrm{OH})_{2}$ added to the control soil. The soil was thoroughly mixed to reduce natural variability of the physical and chemical properties and to ensure homogeneous fertilization.

\section{Relative root growth (RRG)}

Before transferring the seeds to soil, the initial root length of each seedling was measured. After each growth period ( 1 and 3 days), the pots were cut and the soil was gently removed to expose the roots. Each root was washed in running water to remove the excess soil and the root length was measured. Root growth (RG) was calculated as the final length (after growth in soil) minus the initial length. The relative root growth (RRG) of each maize line was calculated as the RG of all the seedlings grown in acid soil divided by the mean RG of all the seedlings grown in control soil times 100 .

\section{Aluminum quantification}

$\mathrm{Al}$ quantification was carried out as described by Bloom et al. [94] after the roots were washed in acidified water ( $\mathrm{pH} 4.0)$. Measurements were performed in a spectrofluorometer (ISS PCI Photon Counting Spectrofluorometer) with lamp intensity of $10 \mathrm{~A}$, emission and excitation gap of $2 \mathrm{~mm}$. The excitation wavelength was $390 \mathrm{~nm}$ and the emission wavelength was $497 \mathrm{~nm}$. Each sample was measured 10 times with a quartz cuvette (optical length of $1 \mathrm{~cm}$ ). A standard curve was made with serial dilutions of $\mathrm{AlCl}_{3}$.

\section{Callose quantification}

Callose content was quantified as described by Jones et al. [95] with modifications. Ten root apexes were fixed in formalin. After $48 \mathrm{~h}$, the solution was replaced with $200 \mu \mathrm{L}$ of $\mathrm{NaOH}(1 \mathrm{M})$ and the root tips were disrupted with the use of a pistile. After $24 \mathrm{~h}$, an additional 800 $\mu \mathrm{L}$ of $\mathrm{NaOH}(1 \mathrm{M})$ was added to each sample and they were placed in a water bath at $80^{\circ} \mathrm{C}$ for 15 minutes. The samples were rapidly centrifuged at $1000 \mathrm{~g}$ after cooling off. A total of $400 \mu \mathrm{L}$ of the upper phase was transferred to a new tube and $800 \mu \mathrm{L}$ of aniline blue solution $(0.1 \%$ - w/v), $420 \mu \mathrm{L}$ of $\mathrm{HCl}(1 \mathrm{M})$ and $1,180 \mu \mathrm{L}$ of glycine/ $\mathrm{NaOH}$ buffer ( $\mathrm{pH}$ 9.5) were added, and they were incubated at $80^{\circ} \mathrm{C}$ for 20 minutes. Callose content was quantified in a spectrofluorometer, as described above, but with an excitation wavelength of $385 \mathrm{~nm}$ and an emission wavelength of $485 \mathrm{~nm}$. Each sample was read 10 times with a quartz cuvette (optical length of $1 \mathrm{~cm}$ ). A 
standard curve was made with serial dilutions of curdlan solution. The amount of Al-induced callose deposition was calculated as the quantity in the acid soil treatment minus the quantity in the control soil treatment.

\section{RNA extraction}

RNA was extracted with an RNeasy Plant Mini Kit (Qiagen, Valencia, USA). The RNA was evaluated in an agarose/formaldehyde gel, quantified in a spectrophotometer and stored at $-80^{\circ} \mathrm{C}$.

\section{Microarray hybridization and analysis}

For the microarray experiment, three independent replicates were used, for a total of 24 samples. Two micrograms of each RNA sample was processed and hybridized to the Affymetrix GeneChip Maize Genome Array as described by the manufacturer's protocol. The hybridization, staining, washing and scanning were performed at Laboratório Nacional de Luz Sincrontron (LNLS), Campinas, SP, Brazil, with the use of the Command Console Software (Affymetrix, USA). The data were normalized with the RMA method, $\log _{2}$ transformed and loaded into SAS (SAS Institute, USA) to perform the contrasts. A one-way analysis of variance (ANOVA) was used to separate the contribution of each effect on the expression level of a given gene. The model used was: $y_{i k l}=\mu+G_{i}+T a_{k}+T e_{l}+(G \times T a)_{i k}$ $+(G \times T e)_{i l}+(G \times T a \times T e)_{i k l}+\xi_{i k l}$ where $\mu$ is the sample mean, $G_{i}$ represents the genotype effect for the $\mathrm{i}^{\text {th }}$ genotype (e.g., Cat100-6 or S1587-17) $(\mathrm{df}=1), T a_{k}$ is the effect of the $\mathrm{k}^{\text {th }}$ Treatment (e.g., acid soil or control soil) $(\mathrm{df}=1), T e_{l}$ is the effect of $\mathrm{l}^{\text {th }}$ time point (e.g., 1 or 3 days) $(\mathrm{df}=1),(G \times T a)_{i k}$ is the effect of interaction between genotype and treatment $(\mathrm{df}=1),(G \times T e)_{i l}$ is the effect of interaction between genotype and time point $(\mathrm{df}=1),(G \times T a \times T e)_{i k l}$ is the effect of interaction between genotype, treatment and time $(\mathrm{gl}=1)$ and $\xi_{i k l}$ is the residual error. Least-square means for each gene in each sample were generated and differential estimates (DE) of expression were calculated as the difference between least-square means for each of the terms in the model. DE values were calculated between the acid and control soil treatments and also between genotypes. The false discovery rate (FDR) was set to $10 \%$ to control Type I errors [96]. Q values were calculated from $P$-values using the software $\mathrm{Q}$-value from the $\mathrm{R}$ platform [97]. Only the genes with DE above 1 were further analyzed. The list of differentially expressed genes was annotated with the use of Blast2GO software http://www.blast2go.org[98-100] using default settings.

\section{Hydroponic culture}

To validate the microarray data and to separate the effect of $\mathrm{pH}$ from that of $\mathrm{Al}$, a hydroponic experiment was performed. The basic solution consisted of $0.5 \mathrm{mM}$ $\mathrm{CaCl}_{2} ; 0.125 \mathrm{mM} \mathrm{MgCl} 2 ; 1 \mathrm{mM} \mathrm{KCl} ; 1 \mathrm{mM} \mathrm{NH}_{4} \mathrm{NO}_{3}$. This basic solution was divided into two portions and their $\mathrm{pHs}$ were corrected to 5.5 (control solution) and 4.2. The solution with the $\mathrm{pH}$ of 4.2 was again divided in two and one portion received $36 \mu \mathrm{M} \mathrm{AlCl}_{3}$. This $\mathrm{Al}$ concentration yielded the same RRG as was obtained with soil treatment (data not shown). The plants were grown in a growth chamber at $26^{\circ} \mathrm{C}$ (light: dark, $16: 8 \mathrm{~h}$ ) with constant solution aeration.

\section{Real Time qPCR}

To validate the microarray results, RNA from two additional independent replicates was treated with DNase I Amplification Grade (Invitrogen, USA) and cDNA was synthesized from $2 \mu \mathrm{g}$ of RNA using High Capacity RNA-to-cDNA Kit (Applied Biosystems, USA). Realtime qPCR for eleven genes identified as differentially regulated in at least one of the experimental conditions was performed with an ABI 7500 (Applied Biosystems, USA) using Sybr Green I PCR Master Mix (Applied Biosystems, USA). The primers were designed using Primer Express 2.0 software (Additional file 2: Table S6). The efficiency of each pair was tested with a relative standard curve experiment. The maize tubulin gene (Zm.6045.1.A1_s_at) was used as an endogenous control. As the efficiency of all the primers was near $100 \%$, the relative expression was calculated by the $\Delta \Delta \mathrm{Ct}$ method. For microarray validation, the $\Delta \mathrm{Ct}$ values were calculated for each gene in each sample, $\log _{2}$ transformed and plotted against its corresponding leastsquare means data from the microarray. For the hydroponic experiment, the $\Delta \Delta \mathrm{Ct}$ values were calculated relative to the $\Delta \mathrm{Ct}$ from the $\mathrm{pH} 5.5$ treatment.

\section{Note}

Accession numbers: The gene expression data were deposited at The Gene Expression Omnibus (GEO) Database under access number GSE21070

Supplementary Materials: Submitted as a additional files

\section{Additional material}

Additional file 1: Figure S1. Root phenotype under control (first and third row) and acid soil (second and fourth row) conditions after one day of treatment (A), three days of treatment (B). Figure S2. Functional analysis of genes differentially expressed in \$1587-17 after one day of treatment in acid soil. A: Up-regulated; B: Down-regulated. All of the genes that did not present Gene Ontologies were removed from the analysis. Figure S3. Functional analysis of genes differentially expressed in S1587-17 after three days of treatment in acid soil. A: Up-regulated; B: Down-regulated. All of the genes that did not present Gene Ontologies were removed from the analysis.

Additional file 2: Table S1: Genes differentially expressed in Cat1006 after one day of acid soil treatment. FDR $=10 \%$ and DE $\leq 1$. Table 
S2: Genes differentially expressed in Cat100-6 after three days of acid soil treatment. FDR $=10 \%$ and DE $\leq 1$. Table S3: Genes differentially expressed in \$1587-17 after one day of acid soil treatment. FDR $=10 \%$ and $D E \leq 1$. Table S4: Genes differentially expressed in \$1587-17 after three days of acid soil treatment. FDR $=10 \%$ and DE $\leq 1$. Table S5 Genes that were differentially expressed in Cat100-6 grown both in soil (this work) and hydroponics [27] and in \$1587-17 grown in soil (this work) and L53 in hydroponics [27]. Table S6: Primers designed for realtime $\mathrm{qPCR}$

\section{Acknowledgements}

This work was supported by grant 07/50993-5 from Fundação de Amparo à Pesquisa do Estado de São Paulo (FAPESP) to MM. LM received a fellowship from FAPESP. We are grateful to Agustina Gentile for helpful comments on the manuscript and Luiz H Fasolin for helping with part of the statistical analyses.

\section{Author details}

'Laboratório de Genoma Funcional, Departamento de Genética, Evolução e Bioagentes, Instituto de Biologia, Universidade Estadual de Campinas, Campinas, SP, Brazil. ${ }^{2}$ School of Forest Resources and Conservation, Plant Molecular and Cellular Biology Program, Genetics Institute, University of Florida, Gainesville, USA. ${ }^{3}$ Empresa Brasileira de Pesquisa Agropecuária, Centro Nacional de Pesquisa de Recursos Genéticos e Biotecnologia, Brasília, DF, Brazil. ${ }^{4}$ Departamento de Fisico-Química, Instituto de Química, Universidade Estadual de Campinas, Campinas, SP, Brazil.

\section{Authors' contributions}

LM designed the experiments; performed the microarray hybridizations, data analysis and interpretation; and drafted the manuscript. MK evaluated the data from the microarrays and edited the manuscript. FRS helped with the comparison of the data from the acid soil and hydroponic experiments. RAJ helped with the experiments in acid soil and interpretation of the data. MM designed the experimental approach, led and coordinated the project and edited the manuscript. All authors have read and approved the final manuscript.

\section{Received: 29 April 2010 Accepted: 9 September 2010}

Published: 9 September 2010

\section{References}

1. Hoekenga OA, Pineros MA: How do crop plants tolerate acid soils? -Mechanisms of aluminum tolerance and phosphorous efficiency. Annu Rev Plant Biol 2004, 55:459-493.

2. Johnson JP, Carver BF, Baligar VC: Productivity in Great Plains acid soils of wheat genotypes selected for aluminium tolerance. Bot Rev 1997, 68:235-269.

3. Sommers LE, Lindsay WL: Effect of $\mathrm{pH}$ and redox on predicted heavy metal-chelate equilibria in soils. Soil Sci Soc Am J 1979, 43(1):39-47.

4. Doncheva S, Amenós M, Poschenrieder C, Barceló J: Root cell parttening: a primary target for aluminum toxicity in maize. J Exp Bot 2005, 56(414):1213-1220

5. Rounds MA, Larsen PB: Aluminum-Dependent Root-Growth Inhibition in Arabidopsis Results from AtATR-Regulated Cell-Cycle Arrest. Curr Biol 2008, 18:1495-1500.

6. Rengel Z: Disturbance of cell Ca-2+ homeostasis as a primary trigger of Al toxicity syndrome. Plant Cell Environ 1992, 15(8):931-938.

7. Huang JW, Grunes DL, Kochian LV: Aluminum effects on the kinetics of calcium uptake into cells of the wheat root apex. Planta 1992, 188:414-421.

8. Sun P, Tian Q-Y, Zhao M-G, Huang J-H, Li L-H, Zhang W-H: Aluminuminduced ethylene production is associated with inhibition of root elongation in Lotus japonicus L. Plant Cell Physiol 2007, 48(8):1229-1235.

9. Yang JL, Li YY, Zhang YJ, Zhang SS, Wu YR, Wu P, Zheng SJ: Cell wall polysaccharides are specifically involved in the exclusion of aluminum from the rice root apex. Plant Physiol 2008, 146:602-611.
10. Rangel AF, Rao IM, Horst WJ: Intracellular distribution and binding state of aluminum in root apices of two common bean (Phaseolus vulgaris) genotypes in relation to Al toxicity. Physiol Plant 2009, 135(2):162-173.

11. Chaffai R, Marzouk B, El Ferjani E: Aluminum mediates compositional alterations of polar lipid classes in maize seedlings. Phytochemistry 2005, 66(16):1903-1912.

12. Taylor GJ: The physiology of aluminum phytotoxicity. In Metal lons in Biological System. Aluminum and Its Role in Biology.Edited by: Sigel $\mathrm{H}$, Sigel A. Marcel Dekker; 1988:24:123-163.

13. Wenzl P, Pateño GM, Chaves AL, Mayer JE, Rao IM: The high levels of aluminum resistence in signalgrass is not associated with known mechanisms of external aluminum detoxification in root apices. Plant Physiol 2001, 125:1473-1484.

14. Tolrà RP, Poschenrieder C, Luppi B, Barceló J: Aluminium-induced changes in the profiles of both organic acids and phenolic substances underlie Al tolerance in Rumex acetosa L. Environ Exp Bot 2005, 54:231-238.

15. Poschenrieder $C$, Tolrà RP, Barceló J: A role for cyclic hydroxamates in aluminum resistance in maize? J Inorg Biochem 2005, 99:1830-1836.

16. Kochian LV: Cellular mechanisms of aluminum toxicity and resistence in plants. Annu Rev Plant Physiol Plant Mol Biol 1995, 46:237-260.

17. Delhaize E, Ryan PR: Aluminum toxicity and tolerance in plants. Plant Physiol 1995, 107:315-321.

18. Kitagawa T, Morishita T, Tachibana Y, Namai H, Ohta Y: Genotypic variations in $\mathrm{Al}$ resistance in wheat and organic acid secretion. Japan Journal of Soil Science and Plant Nutrition 1986, 57:352-358.

19. Miyasaka SC, Buta JG, Howell RK, Foy CD: Mechanisms of aluminum tolerance in snapbeans. Root exudation of citric acid. Plant Physiol 1991, 96:737-743.

20. Delhaize E, Ryan PR, Randall J: Aluminum tolerance in wheat (Triticum aestivum L.). II. Aluminum-stimulated excretion of malic acid from root apexes. Plant Physi 1993, 103:695-702.

21. Pellet DM, Grunes DL, Kochian LV: Organic acid exudation as an aluminum-tolerance mechanism in maize (Zea mays L). Planta 1995, 196:788-795.

22. Jorge RA, Arruda P: Aluminum-induced organic acids exudation by roots of an aluminum-tolerant tropical maize. Phytochemistry 1997, 45:675-681.

23. Jorge RA, Menossi M, Arruda P: Probing the role of calmodulin in Al toxicity in maize. Phytochemistry 2001, 58:415-422.

24. Mariano ED, Keltjens WG: Evaluating the role of root citrate exudation as a mechanism of aluminum resistance in maize genotypes. Plant Soil 2003, 256:469-479.

25. Jorge RA, Menossi M: Effect of anion channel antagonists and $\mathrm{La}^{3+}$ on citrate release, $\mathrm{Al}$ content and $\mathrm{Al}$ resistance in maize roots. $J$ Inorg Biochem 2005, 99:2039-2045.

26. Piñeros MA, Shaff JE, Manslank HS, Alves VMC, Kochian LV: Aluminum resistance cannot be solely explained by root organic acid exudation $\mathrm{A}$ comparative physiological study. Plant Physiol 2005, 137(Suppl 1):231-241.

27. Zheng SJ, Yang JL, He YF, Yu XH, Zhang L, You JF, Shen RF, Matsumoto H: Immobilization of aluminum with phosphorus in roots is associated with high aluminum resistance in buckwheat. Plant Physiol 2005, 138:297-303.

28. Maron LG, Kirst M, Mao C, Milner JM, Kochian LV: transcriptional profiling of aluminum toxicity and tolerance responses in maize roots. New Phytol 2008, 176(Suppl 1):116-128.

29. Kumari M, Taylor GJ, Deyholos MK: Transcriptomic responses to aluminum stress in roots of Arabidopsis thaliana. Mol Genet Genomics 2008, 279:339-357.

30. Kawasaki S, Borchert C, Deyholos M, Wang H, Brazille S, Kawai K, Galbraith $\mathrm{D}$, Bohnert HJ: Gene expression profile during the inicial phase of salt stress in rice. Plant Cell 2001, 13:889-905.

31. Seki M, Narusaka M, Ishida J, Nanjo T, Fujita M, Oono Y, Kamiya A, Nakajima M, Enju A, Sakurai T, Satou M, Akiyama K, Taji T, YamaguchiShinozaki K, Carninci P, Kawai J, Hayashizaki Y, Shinozaki K: Monitoring the expression profiles at 7000 Arabidopsis genes under drought, cold, and high-salinity stresses using a full-length cDNA microarray. Plant $J$ 2002, 31:279-292.

32. Ozturk ZN, Talame V, Deyholos M, Michalowski CB, Galbraith DW, Gozukirmizi N, Tuberosa R, Bohnert HJ: Monitoring large-scale changes in transcript abundance in drought- and salt-stressed barley. Plant Mol Biol 2002, 48:551-573. 
33. Cançado GMA, Nogueira FTS, Camargo SR, Drummond RD, Jorge RA, Menossi $M$ : Gene expression profiling in maize roots under aluminum stress. Biol Plant 2008, 52(3):475-485.

34. Guo P, Bai G, Carver B, Li R, Bernardo A, Baum M: Transcriptional analysis between two wheat near-isogenic lines contrasting in aluminum tolerance under aluminum stress. Mol Genet Genomics 2007, 277:1-12.

35. Marschener $\mathrm{H}$ : Mechanisms of adaptation of plants to acid soils. Plant Soil 1991, 134:1-20.

36. Myasaka SC, Hawes MC: Possible role of root border cells in detection and avoidance of aluminum toxicity. Plant Physiol 2001, 125:1978-1987.

37. Horst WJ, Wagner A, Marshner H: Mucilage protects root meristems from aluminum injury. Z Pflanzenphysiol 1982, 105:435-444.

38. Archambault DJ, Zhang G, Taylor GJ: Accumulation of Al in root mucilage of an Al-resistant and Al-sensitive cultivar of wheat. Plant Physiol 1996, 112:1471-1478.

39. Li XF, Ma JF, Hiradate S, Matsumoto H: Mucilage strongly binds aluminum but does not prevent roots from aluminum injury in Zea mays. Physiol Plant 2000, 108:152-160.

40. Zhou S, Sauvé R, Thannhauser TW: Proteome changes induced by aluminum stress in tomato roots. J Exp Bot 2009, 60(6):1849-1857.

41. Boscolo RS, Menossi M, Jorge RA: Aluminum-induced oxidative stress in maize. Phytochemistry 2003, 62:181-189.

42. Moon DH, Ottoboni LMM, Souza AP, Sibov ST, Gaspar M, Arruda P: Somaclonal-variation-induced aluminium-sensitive mutant from an aluminium-inbred maize tolerant line. Plant Cell Rep 1997, 16:686-691.

43. Piñeros MA, Cançado GMA, Maron LG, Lyi SM, Menossi M, Kochian LV: Not all ALMT1-type transporters mediate aluminum-activated organic acid reponses: the case of ZmALMT1 - an anion-selective transporter. Plant J 2008, 53:352-367.

44. Sibov ST, Gaspar M, Silva MJ, Ottoboni LMM, Arruda P, Souza AP: Two genes control aluminum tolerance in maize: Genetic and molecular mapping analyses. Genome 1999, 42:475-482.

45. Wissemeier AH, Diening A, HergenröDer A, Horst WJ, Mix-Wagner G: Callose formation as parameter for assessing genotypical plant tolerance of aluminium and manganese. Plant Soil 1992, 146:67-75.

46. Llugany M, Massot N, Wissemeier AH, Poschenrieder CJ, Horst WJ, Barcelo J: Al tolerance of maize cultivars as assessed by callose production and root elongation. Z Pflanzenernähr Bodenk 1994, 157:447-451.

47. Zhang G, Hoddinott J, Taylor GJ: Characterization of 1,33-D-glucan (callose) synthesis in roots of Triticum aestivum in response to aluminium toxicity. J Plant Physiol 1994, 144:229-234.

48. Delhaize E, Ryan PR, Hebb DM, Yamamoto Y, Sasaki T, Matsumoto H: Engineering high-level aluminum tolerance in barley with the ALMT1 gene. PNAS 2004, 101(42):15249-15254.

49. Spehar CR: Aluminum tolerance of soya bean genotypes in short term experiments. Euphytica 1994, 76:73-80.

50. Wenzl P, Mancilla LI, Mayer JE, Albert R: Simulating infertile acid soils with nutrient solutions: The effect on Brachiaria species. Soil Sci Soc Am J 2003, 67:1457-1469.

51. Delhaize E, Ryan PR, Hocking PJ, Richardson AE: Effects of altered citrate synthase and isocitrate dehydrogenase expression on internal citrate concentrations and citrate enflux from tobacco (Nicotiana tabacum L.) roots. Plant Soil 2003, 248:137-144.

52. Anoop VM, Basu U, Mccammon MT, Mcalister-Henn L, Taylor GJ: Modulation of citrate metabolism alters aluminum tolerance in yeast and transgenic canola overexpressing a mitochondrial citrate synthase. Plant Physiol 2003, 132:2205-2217.

53. Sasaki T, Yamamoto Y, Ezaki B, Katsuhara M, Ahn SJ, Ryan PR, Delhaize E, Matsumoto $\mathrm{H}$ : A wheat gene enconding an aluminum-activated malate transporter. Plant J 2004, 37:645-653.

54. Sartain JB, Kamprath EJ: Aluminum tolerance of soybean cultivars based on root elongation in solution culture compared with growth in acid soil. Agron J 1978, 70:17-20.

55. Noble AD, Lea JD, Fey MV: Performance of five soybean cultivars in relation to lime and phosphorus levels on acid Ultisol. S Afr J Plant Soil 1987, 4:140-142.

56. Delhaize E, Taylor P, Hocking PJ, Simpson RJ, Ryan PR, Richardson AE: Transgenic barley (Hordeum vulgare L.) expressing the wheat aluminium resistance gene (TaALMT1) shows enhanced phosphorus nutrition and grain production when grown on acid soil. Plant Biotech J 2009, 7:391-400
57. Baier AC, Somers DJ, Gustafson JP: Aluminium tolerance in wheat: correlating hydroponic evaluations with field and soil performances. Plant Breed 1995, 14:291-296.

58. Urrea-Gómez R, Ceballos H, Pandey S, Bahia Filho AFC, León LA: A greenhouse screening technique for acid soil tolerance in maize. Agron $J$ 1996, 88:806-812.

59. Ma JF, Taketa S, Yang ZM: Aluminum tolerance genes on the short arm of chromosome $3 \mathrm{R}$ are linked to organic acid release in triticale. Plant Physiol 2000, 122:687-694.

60. Kobayashi Y, Furuta Y, Ohno T, Hara T, Koyama H: Quantitative trait loci controlling aluminium tolerance in two accessions of Arabidopsis thaliana (Landsberg erecta and Cape Verde Islands). Plant Cell Environ 2005, 28:1516-1524.

61. Kirkpatrick HC, Thompson JM, Edwards JH: Effects of aluminum concentration on growth and chemical composition of peach seedlings. Hort Science, Alexandria 1975, 10:132-134.

62. Wersuhn G, Kalettka T, Gienapp R, Reinke G, Schulz D: Problems posed by in vitro selection for aluminium-tolerance when using cultivated plant cells. J Plant Physiol 1994, 143:92-95.

63. Kinraide TB: Toxicity factors in acidic forest soils: attempts to evaluete separately the toxic effects of excessive $\mathrm{Al}^{+}$and $\mathrm{H}^{+}$and insufficient $\mathrm{Ca}^{2}$ ${ }^{+}$and $\mathrm{Mg}^{2+}$ upon root elongation. E J Soil Science 2003, 54:323-333.

64. Yamamoto $Y$, Kobayashi $Y$, Matsumoto $\mathrm{H}$ : Lipid peroxidation is an early symptom triggered by aluminum, but not the primary cause of elongation inhibition in pea roots. Plant Physiol 2001, 125:199-208.

65. Larsen PB, Degenhardt J, Tai C-Y, Stenzler LM, Howell SH, Kochian LV: Aluminum-resistant Arabidopsis mutants that exhibited altered patterns of aluminum accumulation and organic acid release from roots. Plant Physiol 1998, 117:9-18.

66. Houde M, Diallo AO: Identification of genes and pathways associated with aluminum stress and tolerance using transcriptome profiling of wheat near-isogenic lines. BMC Genomics 2008, 9:400.

67. Coupe SA, Taylor JE, Isaac PG, Roberts JA: Caracterization of a mRNA that accumulates during development of oilseed rape pods. Plant $\mathrm{Mol} B i \mathrm{O}$ 1994, 24(1):223-227.

68. Cheng W-H, Endo A, Zhou L, Penney J, Chen H-C, Arroyo A, Leon P, Nambara E, Asami T, Seo M, Koshiba T, Sheen J: A unique short-chain dehydrogenase/reductase in Arabidopsis glucose signaling and absisic acid biosynthesis and functions. Plant Cell 2002, 14:2723-2743.

69. Eulgem T, Rushton PJ, Robatzek S, Somssich IE: The WRKY superfamily of plant transcription factors. Trends Plant Sci 2000, 5:199-206.

70. Marè C, Mazzucotelli E, Crosatti C, Francia E, Stanca AM, Cattivelli L: HvWRKY38: a new transcription factor involved in cold- and droughtresponse in barley. Plant Mol Biol 2004, 55:399-416.

71. Fowler S, Thomashow F: Arabidopsis transcriptome profiling indicates that multiple regulatory pathways are activated during cold acclimation in addition to the CBF cold response pathway. Plant Cell 2002, 14:1675-1690

72. Goodwin SB, Sutter TR: Microarray analysis of Arabidopsis genome response to aluminum stress. Biol Plant 2009, 53(1):85-99.

73. Klimasauskas S, Weinhold E: A new tool for biotechnology: AdoMetdependent methyltransferases. Trends Plant Biol 2008, 25(3):99-104.

74. Joshi CP, Chiang VL: Conserved sequence motifs in plant S-adenosyl-Lmethionine-dependent methyltransferases. Plant Mol Biol 1998, 37:663-674.

75. Fukuda T, Saitoa A, Wasakib J, Shinanob J, Osaki M: Metabolic alterations proposed by proteome in rice roots grown under low $\mathrm{P}$ and high Al concentration under low pH. Plant Sci 2007, 172:1157-1165.

76. Zhao C-R, Ikka T, Sawaki Y, Kobayashi Y, Suzuki Y, Hibino Y, Sato S, Sakura N, Shibata D, Koyama H: Comparative transcriptomic characterization of aluminum, sodium chloride, cadmium and copper rhizotoxicities in Arabidopsis thaliana. BMC Plant Biol 2009, 9:32.

77. Ma JF: Role of organic acid in detoxification of aluminum in higher plants. Plant Cell Physiol 2000, 41(4):383-390.

78. Cançado GMA, de Rosa VE, Fernadez JH, Maron LG, Jorge RA, Menossi M: Glutathione S-transferase and aluminum toxicity in maize. Funct Plant Biol 2005, 32(Suppl 11):1045-1055.

79. Giannakoula A, Moustakas M, Mylona P, Papadakis I, Yupsanis T: Aluminum tolerance in maize is correlated with increased levels of mineral nutrients, carbohydrates and proline, and decreased levels of lipid 
peroxidation and aluminum accumulation. J Plant Physiol 2007, 165:385-396.

80. Cakmak I, Horst WJ: Effect of aluminum on lipid peroxidation, superoxide dismutase, catalase, and peroxidase activities in root tips of soybean (Glycine max). Plant Physiol 1991, 83:463-468.

81. Yamamoto $Y$, Kobayashi $Y$, Matsumoto H: Lipid peroxidation is an early symptom triggered by aluminum, but not the primary cause of elongation inhibition in pea roots. Plant Physiol 2001, 125:199-208.

82. Ikegawa $\mathrm{H}$, Yamamoto $\mathrm{Y}$, Matsumoto $\mathrm{H}$ : Responses to aluminum of suspension-cultured tobacco cells in a simple calcium solution. Soil Sci Plant Nutr 2000, 46(Suppl 2):503-514.

83. Ono K, Yamamoto Y, Hachiya A, Matsumoto H: Synergistic inhibition of root growth by aluminum and iron of tobacco (Nicotiana tabacum L.) cells in suspention culture. Plant Cell Physiol 1995, 36:115-125.

84. Yamamoto $\mathrm{Y}$, Hachiya A, Matsumoto $\mathrm{H}$ : Oxidative damage to membrane by combination of aluminum and iron in suspention-culture tobacco cells. Plant Cell Physiol 1997, 38:1333-1339.

85. Cordoba-Pedregosa M, Gonzalez-Reyes JA, Canadillas M, Navas P, Cordoba F: Role of apoplastic and cell-wall peroxidases on the stimulation of root enlogation by ascorbate. Plant Physiol 1996, 112(3):1119-1125.

86. Bernier F, Berna A: Germins and germin-like proteins: plant do-all proteins. But what they do exactly? Plant Physiol Biochem 2001, 39:545-554.

87. Sasaki M, Yamamoto Y, Matsumoto H: Lignin deposition induced by aluminum in wheat (Triticum aestivum) roots. Physiol Plant 1996, 96(2):193-198.

88. Mao C, Yi K, Yang L, Zheng B, Wu Y, Liu F, Wu P: Identification of aluminum-regulated genes by CDNA-AFLP in rice (Oryza sativa L.): aluminum-regulated genes for the metabolism of cell wall components. J Exp Bot 2004, 55:137-143.

89. Ponce G, Barlow PW, Cassab Gl: Auxin and ethylene interactions control mitotic activity of the quiescent centre, root cap size, and pattern of cap cell differentiation in maize. Plant Cell Environ 2005, 28:719-732.

90. Santner A, Estelle M: Recent advances and emerging trends in plant hormone signaling. Nature 2009, 459:1071-1078.

91. Gallie DR, Geisler-Lee J, Chen J, Jolley B: Tissue-specific expression of the ethylene biosynthetic machinery regulates root growth in maize. Plant Mol Biol 2009, 69:195-211.

92. Massot N, Nicander B, Barceló J, Poschenrieder C, Tillberg E: A rapid increase in cytokinin levels and enhanced ethylene evolution precede $\mathrm{Al}^{3+}$-induced inhibition of root growth in bean seedlings (Phaseolus vulgaris L.). Plant Growth Regul 2002, 37:105-112.

93. Whalen MC, Feldman $L$ : The effect of ethylene on root growth of Zea mays seedlings. Can J Bot 1988, 66:719-723.

94. Bloom PR, Weaver RM, Mcbride MC: The spectrophotometric and fluorometric determination with 8-hydroxyquinoline and butyl acetate extraction. Soil Sci Soc Am J 1978, 42:713-716.

95. Jonesw DL, Blancaflor EB, Kochian LV, Gilroy S: Spatial coordination of aluminum uptake, production of reactive oxygen species, callose production and wall rigidification in maize roots. Plant Cell Environ 2006, 29:1309-1318.

96. Benjamini $Y$, Hichberg $Y$ : Controlling the false discovery rate - a practical and powerful approach to multiple testing. J R Stat Soc Ser B 1995, 57:289-300.

97. Storey JD, Tibshirani R: Statistical significance for genome-wide experiments. Proc Natl Acad Sci USA 2003, 100:9440-9445.

98. Götz S, García-Gómez JM, Terol J, Williams TD, Nueda MJ, Robles M, Talón M, Dopazo J, Conesa A: High-throughput functional annotation and data mining with the Blast2GO suite. Nucleic Acids Res 2008, 36(10):3420-3435.

99. Conesa A, Götz S, García-Gomez JM, Terol J, Talón M, Robles M: Blast2GO: A universal tool for annotation, visualization and analysis in functional genomics research. Bioinformatics 2005, 21:3674-3676.

100. Conesa A, Götz S: Blast2GO: A comprehensive suite for functional analysis in plant genomics. Int J Plant Genomics 2008, 619-832.

doi:10.1186/1471-2229-10-196

Cite this article as: Mattiello et al.: Transcriptional profile of maize roots under acid soil growth. BMC Plant Biology 2010 10:196.

\section{Submit your next manuscript to BioMed Central and take full advantage of:}

- Convenient online submission

- Thorough peer review

- No space constraints or color figure charges

- Immediate publication on acceptance

- Inclusion in PubMed, CAS, Scopus and Google Scholar

- Research which is freely available for redistribution 